\title{
Squamous carcinoma of the breast
}

\author{
P. S. HASLETON, K. A. MISCH, K. S. VASUDEV, AND D. GEORGE
}

From the Departments of Pathology and Surgery, University Hospital of South Manchester, Department of Pathology, University of Manchester and Department of Pathology, Lister Hospital, Stevenage, Herts, UK

SUMMARY Two cases of primary squamous carcinoma of the breast are described. One of the tumours appeared to have an origin in an epidermoid cyst and had a pseudosarcomatous stroma. The other tumour arose from metaplastic ductal epithelium. A review of the literature is given.

Squamous carcinoma of the breast is a rare tumour. The Fascicle of the Armed Forces Institute of Pathology, on breast tumours (McDivitt et al., 1968), while mentioning the frequency of squamous metaplasia in breast tumours, does not describe a case of primary squamous carcinoma of the breast. Similarly, in a recent review of 1000 cases of invasive breast cancer (Fisher et al., 1975), not one case of squamous carcinoma was recorded. In this communication we describe two squamous carcinomas of the breast with interesting features. One had a probable origin from an epidermoid cyst in the breast, and in one case there was a pseudosarcomatous reaction to the tumour.

\section{Case Reports}

CASE 1

The patient was a 64-year-old married woman who had borne two children. Both children had been bottle-fed. She was seen in the breast clinic on 20 August 1976 with a history of a lump in the left breast of nine months' duration. The lump had been painful on occasions and she was aware of an inincrease in size. She had lost 1.5 stones $(9.53 \mathrm{~kg})$ in weight. There was no history of previous breast disease or discharge from the nipple. The menopause had been at the age of 50 years.

On examination there was a clinical carcinoma, $4.0 \mathrm{~cm}$ in diameter, in the lower outer quadrant of the left breast. The skin was tethered but there was no ulceration. Nodes were felt in the left axilla.

The right breast and axilla were normal. Mammography showed an opacity, measuring approximately $3.0 \mathrm{~cm}$, in the lower outer quadrant of the left breast. The opacity was noted to have irregular margins and the radiological features of malig-

Received for publication 21 July 1977 nancy. Radiographs of the chest, dorsal and lumbar spine, pelvis, and skull showed no evidence of metastases. A left radical mastectomy was performed on 24 August 1976. A cyst was found in the middle of the tumour and the cyst contained opalescent fluid.

\section{Histopathological findings}

In the specimen received there was a carcinoma, $3.5 \mathrm{~cm}$ in diameter and $3.0 \mathrm{~cm}$ in depth, in the lower outer quadrant of the left breast. The tumour had no connection with the skin surface. In the centre of the tumour there was a cystic cavity, $2.0 \mathrm{~cm}$ in diameter. The central part of the breast showed fibroadenosis. The central cystic cavity was lined by squamous epithelium. The epithelium showed severe dysplasia in many areas (Fig. 1) with large nuclear-cytoplasmic ratios and mitoses. This epithelium tended to lift away from the underlying tissue (Fig. 2). In areas the epithelium was frankly carcinomatous and dipped into the underlying breast tissue (Fig. 3). The infiltrative squamous carcinoma varied from poorly differentiated to well differentiated areas (Fig. 4).

No other histological type of breast tumour was identified. There was a marked fibroblastic response to the tumour, some of the elongated cells being attenuated tumour cells. There were few mitoses in $\mathcal{N}$ the fibrous tissue and no cellular pleomorphism. $N$ There was a marked plasma-cell infiltrate in the N fibroblastic tissue as well as some foci of lymphocytes.

Foci of elastosis were present. The tumour was infiltrating into the adjacent adipose tissue of the breast but there was no lymphatic or vascular: infiltration.

Smaller cysts were identified in the tumour. Some $\underset{\mathbb{D}}{\stackrel{D}{0}}$ of these were obviously formed from islands of $\frac{\Omega}{\mathbb{Q}}$ squamous carcinoma (Fig. 5). A block from the 


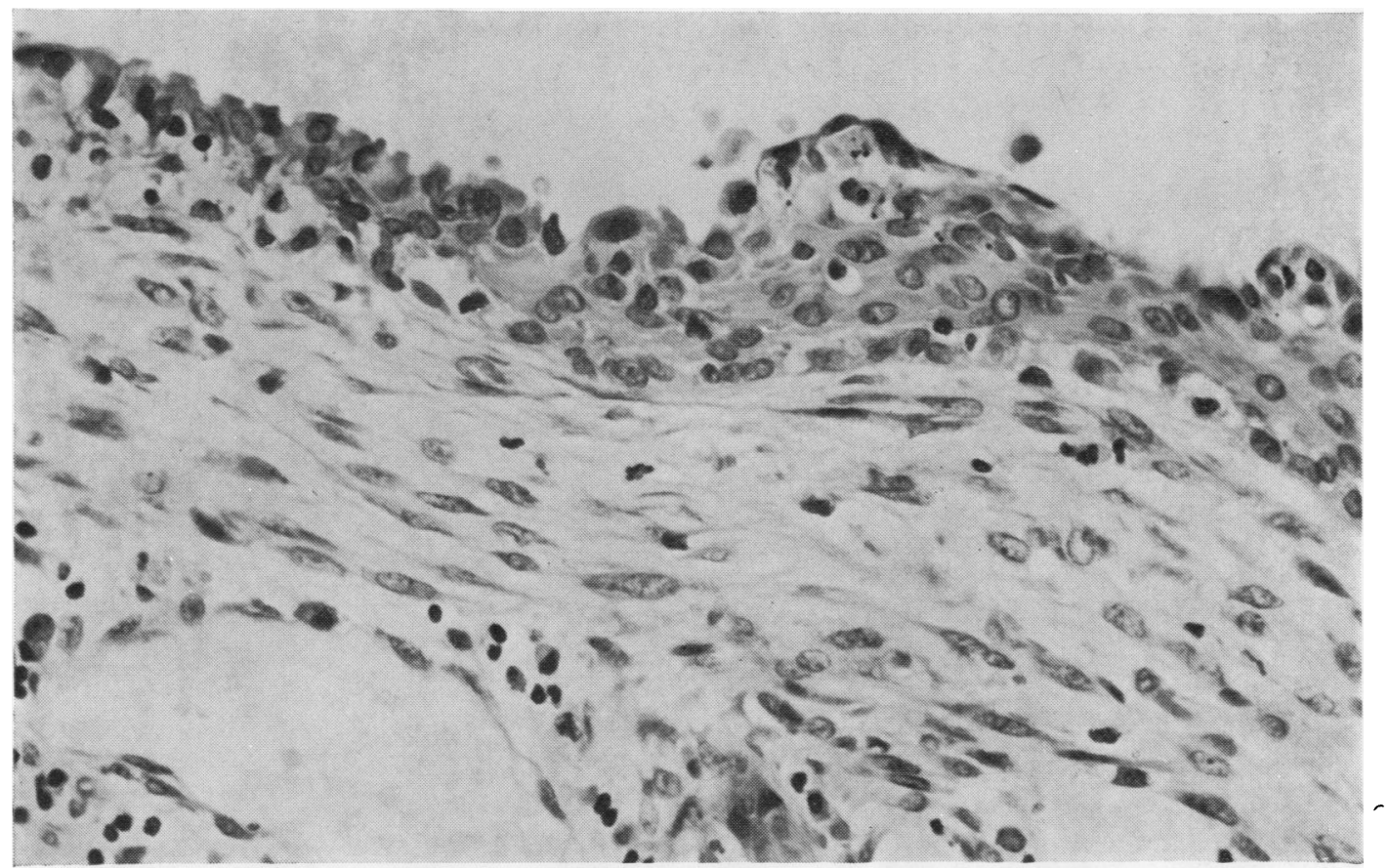

Fig. 1 Case 1. Cyst wall lined by dysplastic epithelium. Tumour cells are seen below the epithelial lining along with stroma. (Haematoxylin and eosin $\times 415$ )

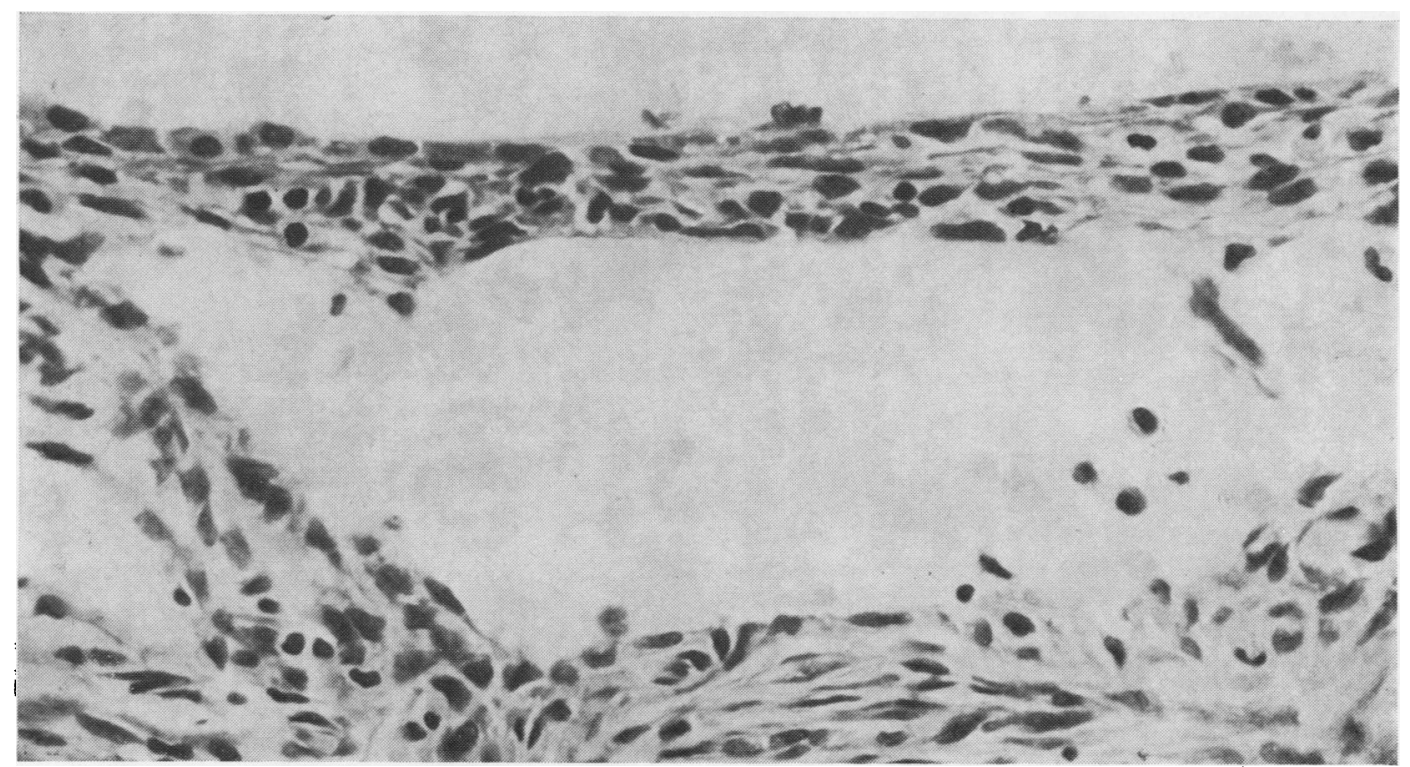

Fig. 2 Case 1. Dysplastic epithelium having separated from underlying tissue. ( $H$ and $E \times 495)$ 


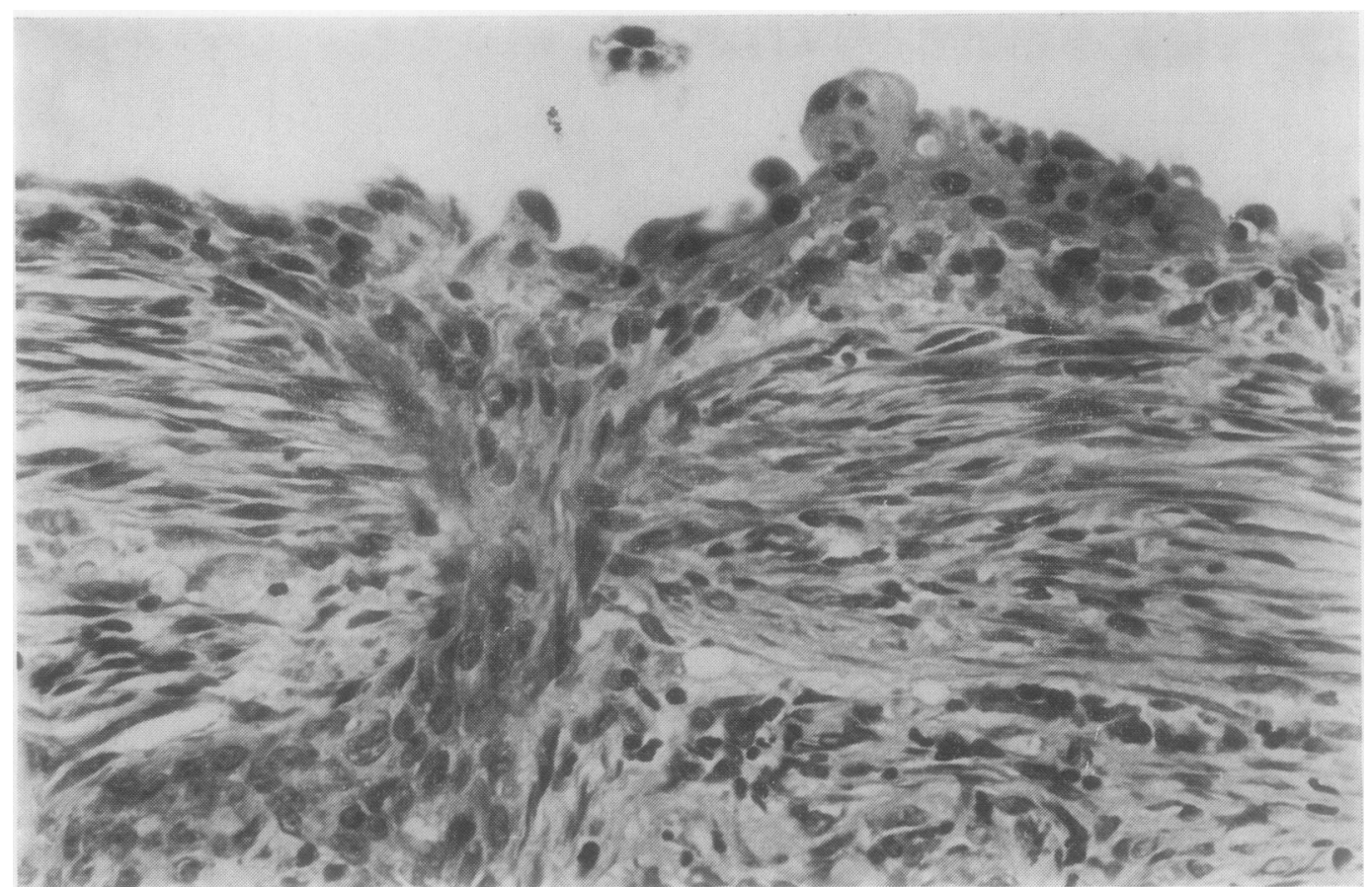

Fig. 3 Case 1. Focus showing dysplastic epithelium and a central area of invasive carcinoma. The cystic cavity lies at the top of the picture. $(H$ and $E \times 375)$

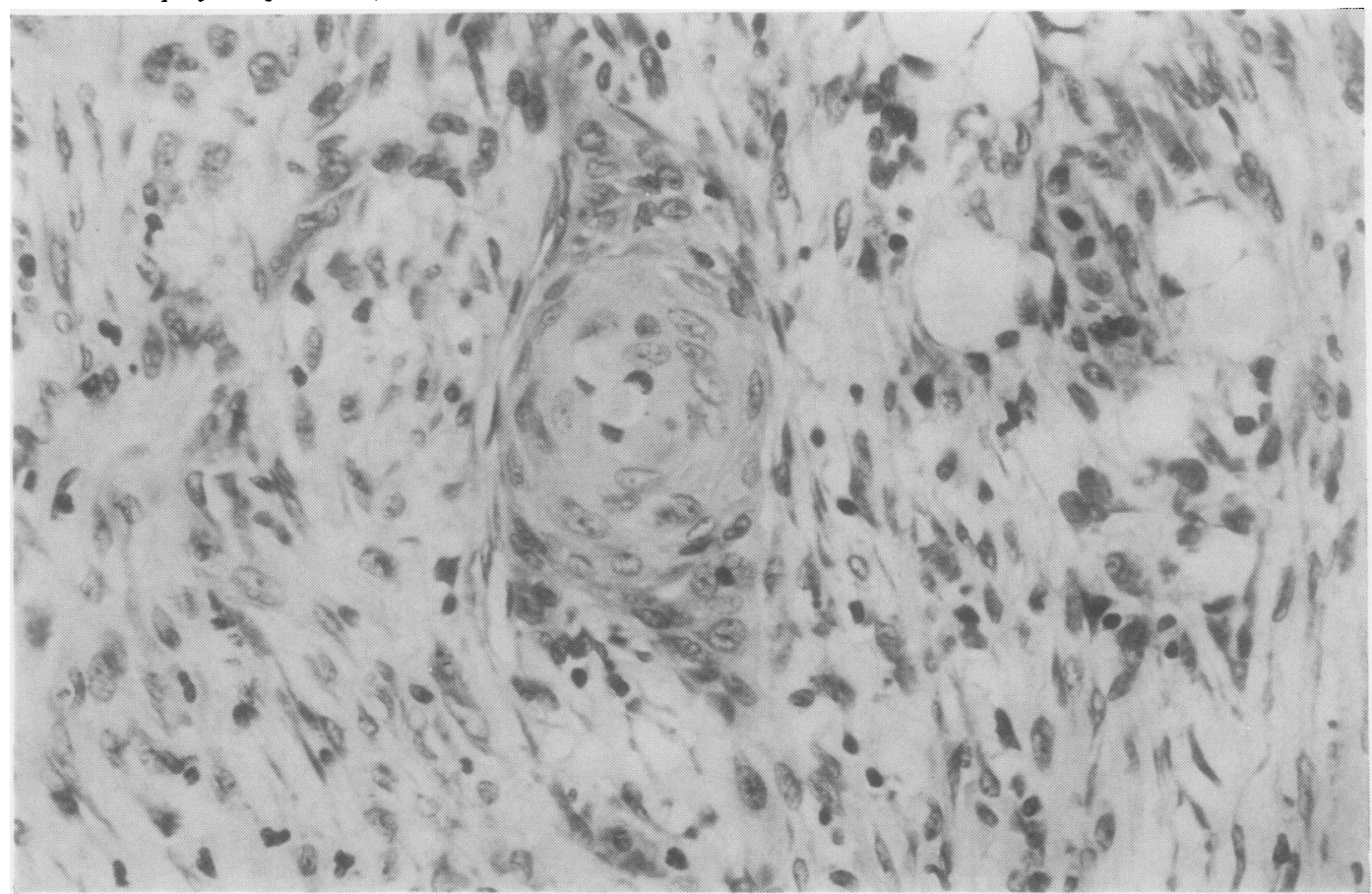

Fig. 4 Case 1. Nests of well differentiated squamous carcinoma cells amidst a pseudosarcomatous stroma. ( $H$ and $E \times 415$ ) 


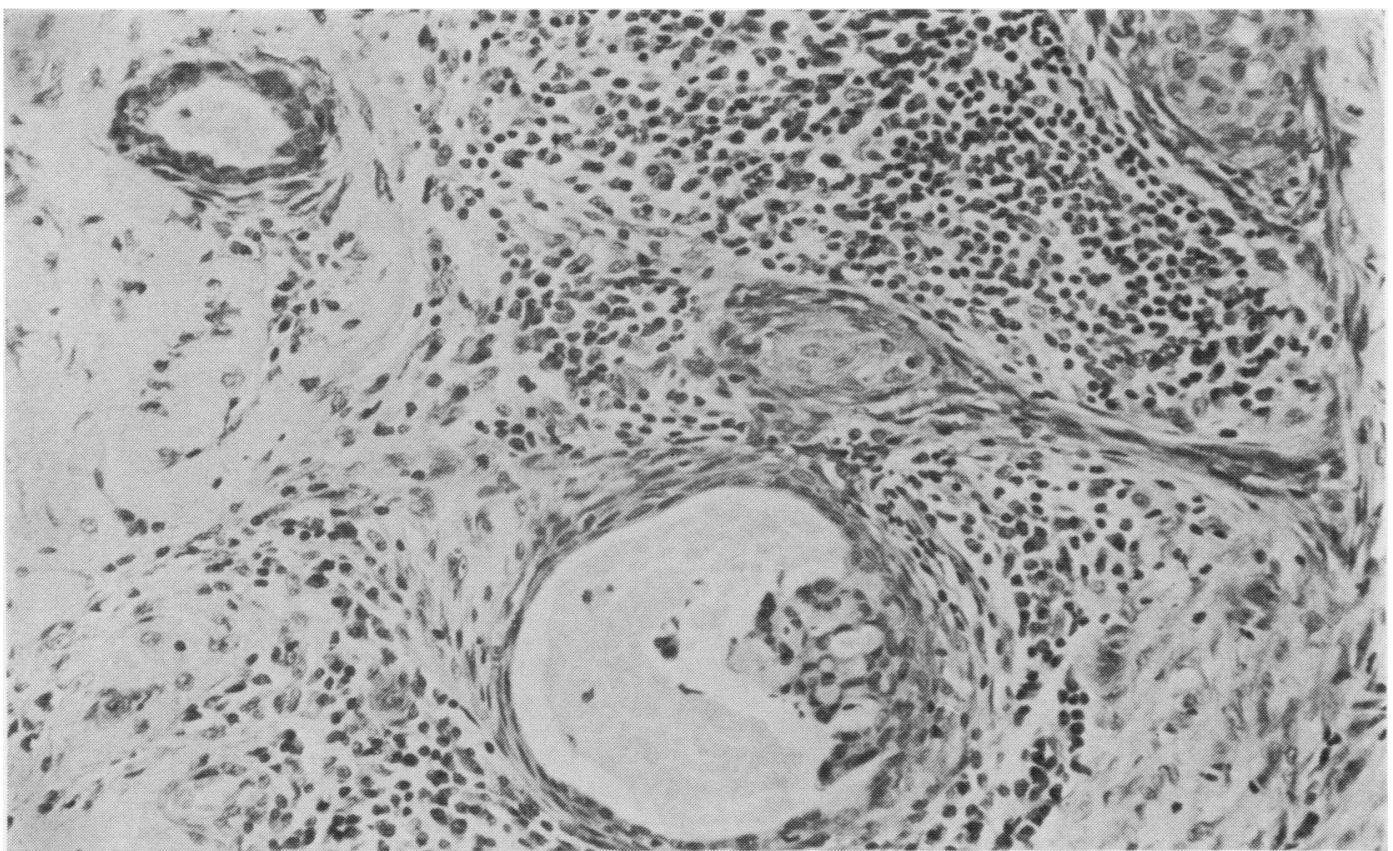

Fig. 5 Case 1. Cyst developing in a focus of squamous carcinoma with an area of elastosis to the left.

( $H$ and $E \times 260)$

lower outer quadrant away from the tumour showed papillomatosis, pink cell change, and florid sclerosing adenosis. In the focus of fibroadenosis referred to above, there was sclerosing adenosis with calcification, pink cell change, and dilatation of ducts. The nipple was histologically normal with no evidence of Paget's disease of the breast. The eight lymph nodes found showed no evidence of any secondary tumour.

\section{CASE 2}

A married woman aged 63 years, who had no children, presented with one week's history of a mass in the upper inner quadrant of the right breast. There had been no previous operations on the breast. At operation the surgeon found a cystic swelling 'the size of a plum' with a ragged papilloma within it. A breast biopsy was followed by a simple mastectomy.

\section{Histological findings}

The breast biopsy specimen consisted of an opened cyst, $5.0 \mathrm{~cm}$ in diameter. On one opened surface there was a soft, white, ragged elevation, $2.5 \mathrm{~cm}$ in

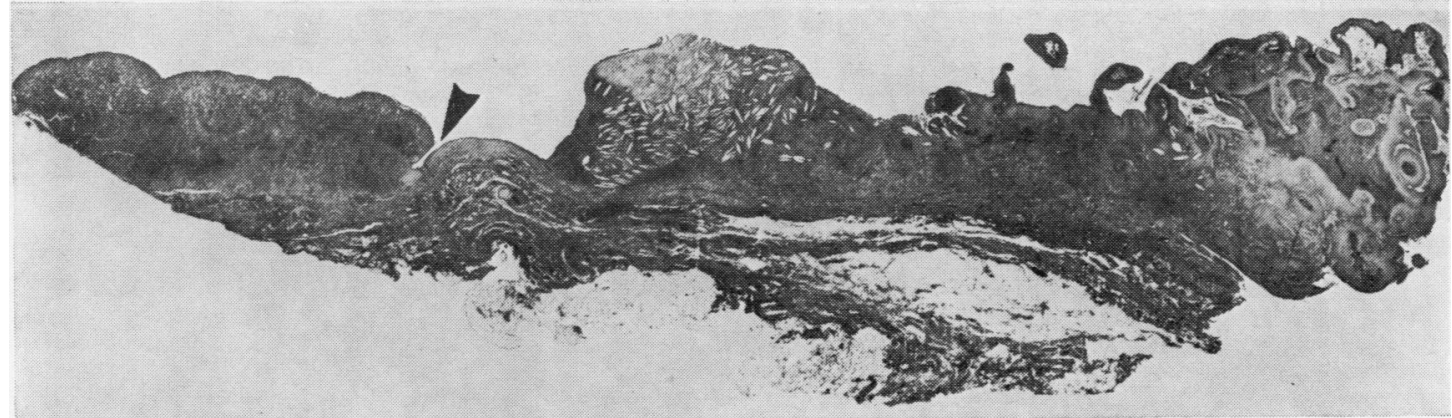

Fig. 6 Case 2. Lining of cyst wall. Arrow points to area with ductal type epithelium shown in Fig. 7. ( $H$ and $E \times 6)$ 


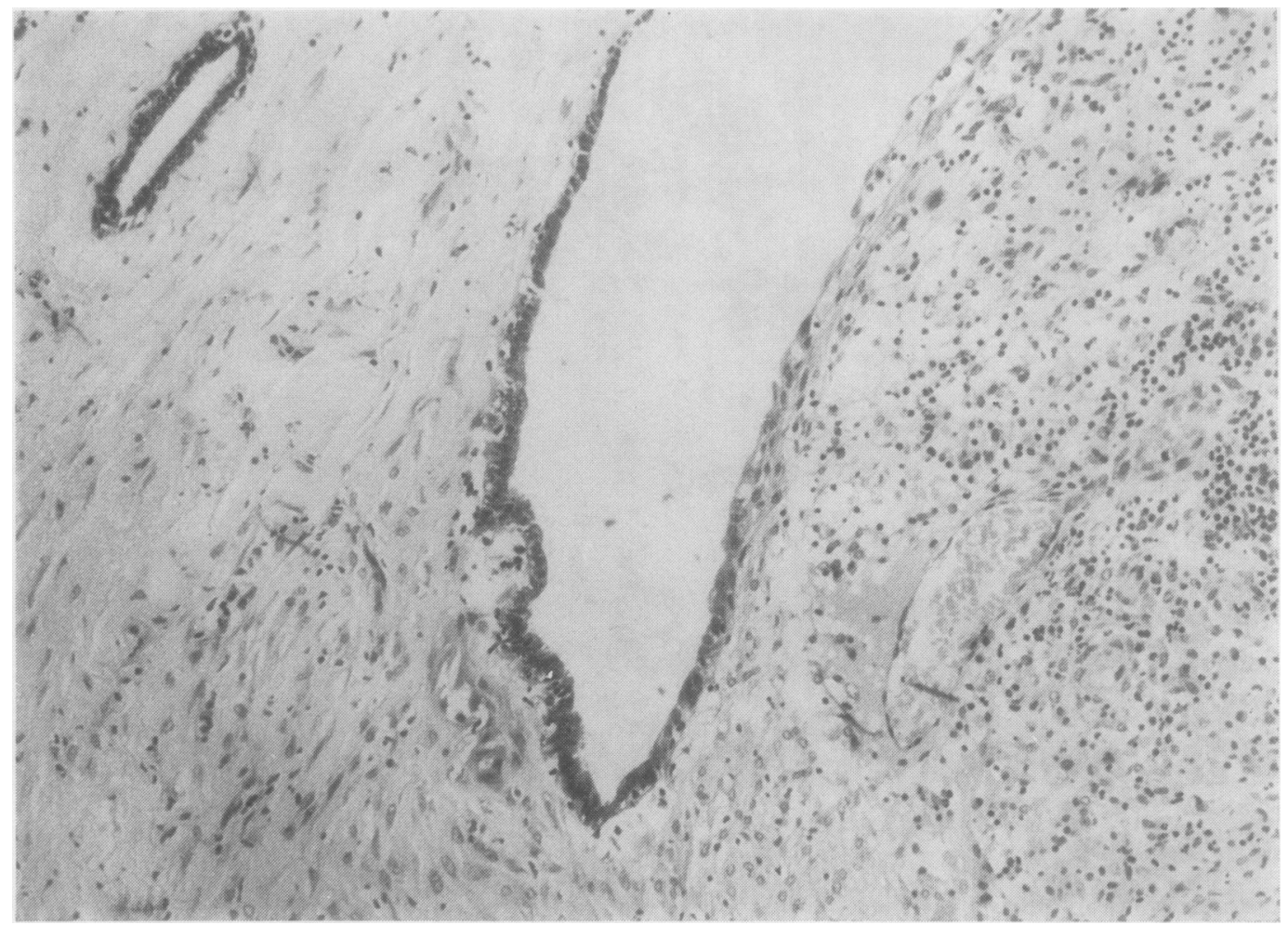

Fig. 7 Case 2. From area shown in Fig. 6. Focus of ductal type epithelium lining the cyst. ( $H$ and $E \times 95)$

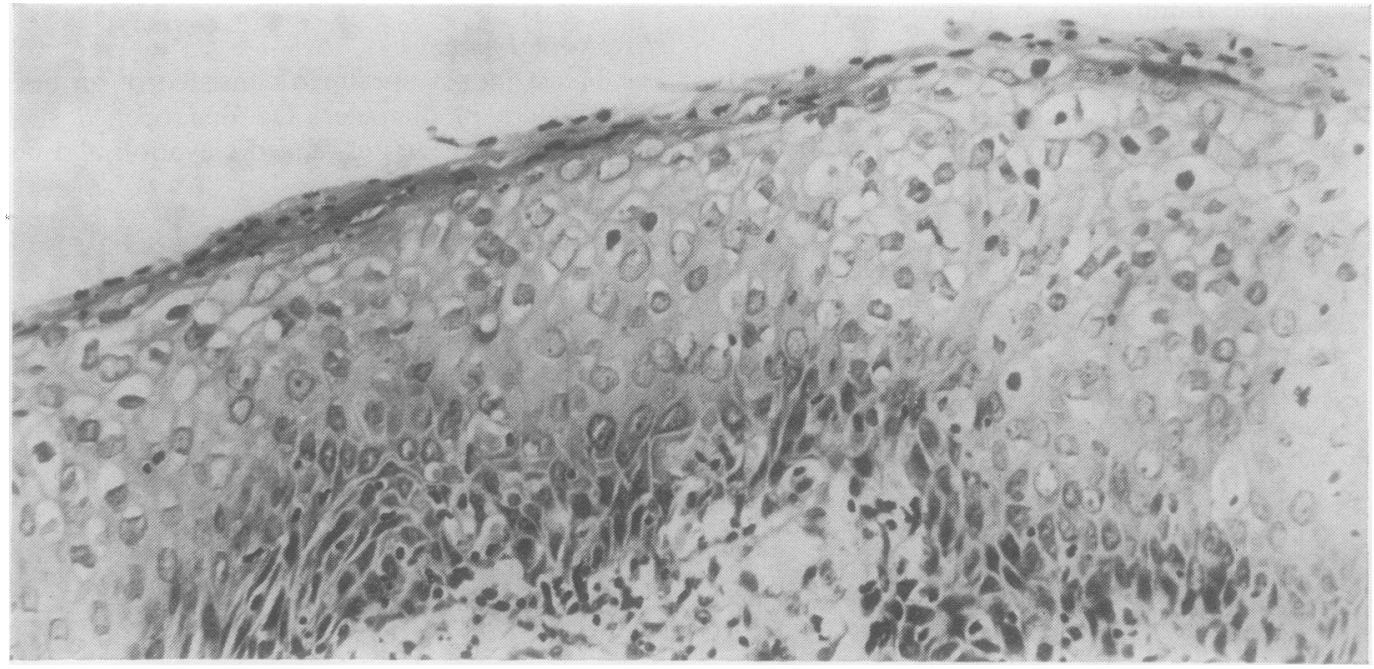

Fig. 8 Case 2. Focus of mildly dysplastic epithelium lining the cyst. $(H$ and $E \times 242)$ 


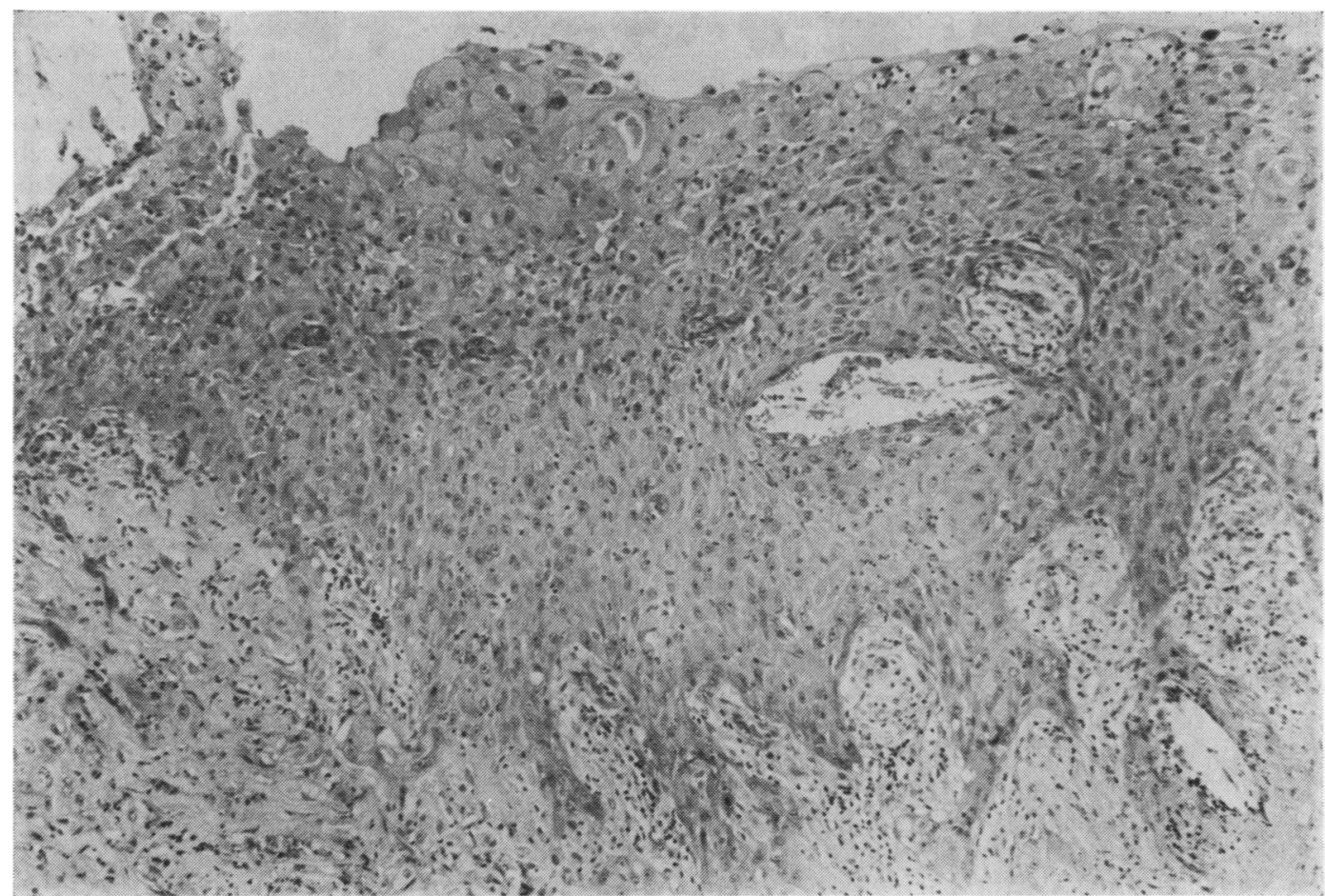

Fig. 9 Case 2. Infiltrating squamous carcinoma. ( $H$ and $E \times 96)$

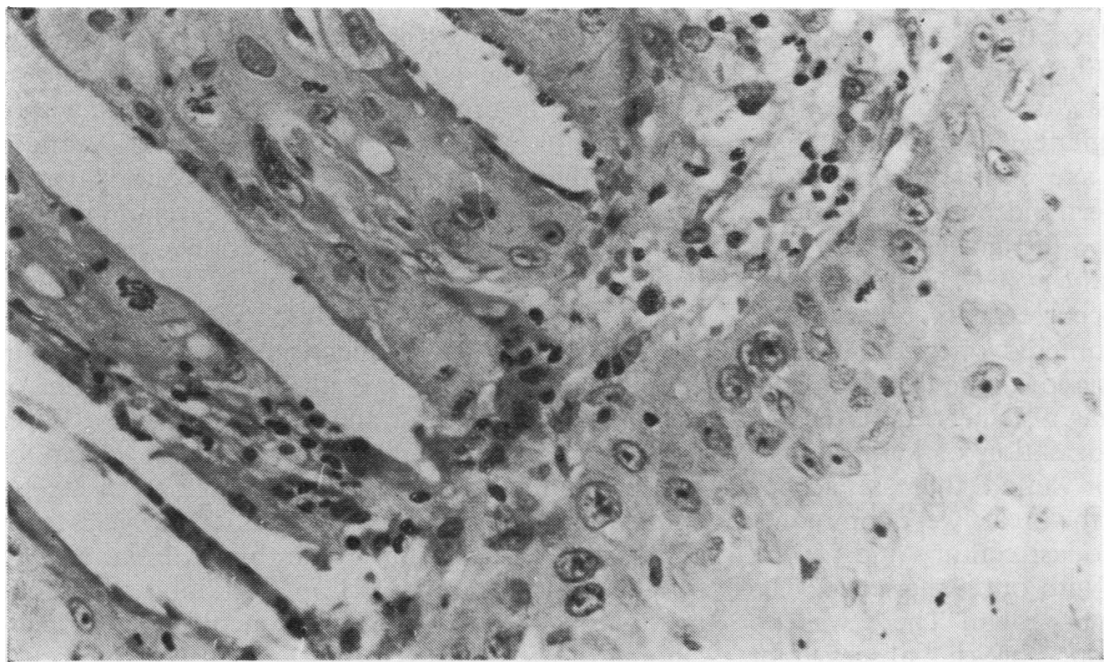

Fig. 10 Case 2.

Cholesterol clefts with associated giant cells and malignant squamous epithelium.

( $H$ and $E \times 460$ ) 
diameter. The tumour had no connection with the skin surface.

There was an epithelial lining to the cyst (Fig. 6), which showed a variation from ductal type epithelium (Fig. 7), mildly dysplastic squamous epithelium (Fig. 8), severely dysplastic epithelium to invasive well differentiated squamous carcinoma (Fig. 9). The elevation mentioned above consisted of acicular cholesterol clefts with associated fibrosis, foreign body giant cells, and adjacent foci of squamous carcinoma (Fig. 10). Keratin production was present in the tumour and epithelial perls were seen. There was a moderate lymphocytic response at the periphery of the tumour. No other histological type of breast tumour was identified. In the mastectomy specimen there was no residual tumour. Four lymph nodes were found and they contained no secondary tumour. The nipple was histologically normal.

\section{Discussion}

One of these tumours (case 1) appears to have arisen in an epidermoid cyst of the breast. The second tumour (case 2) appeared to have an origin in metaplastic ductal epithelium. Dysplastic change in the epithelial linings of both cysts was present, and in areas frank squamous carcinoma was seen infiltrating into the underlying breast tissue. There was no visible connection of either tumour with the skin, thus excluding an origin from the epidermis.

Menville (1936) collected 36 epidermoid cysts of the breast out of a total of 3000 breast lesions. Twenty-nine of these epidermoid cysts were benign and seven were malignant. In the benign cases the cyst was of variable size, sometimes hard, regular, mobile, and usually painless. In half the cases the cyst was an incidental finding. Many of the changes seen in the epidermoid cysts of the skin were noted, that is, inflammation and giant cell formation. There was no difference in the age of the women with benign or malignant epidermoid cysts, the average age of the patients with the benign lesion being 58 years and with the malignant cyst 54 years. Epidermoid cysts are a rare occurrence in breast pathology. We have not encountered one example in a review of 2191 breast biopsies over the last five years.

Squamous metaplasia has also been described in fibroadenomas with the formation of keratin cysts (Salm, 1957). This author stated that 'sebaceous cyst' and 'dermoid cyst' of the breast were commonly described at the end of the last century and yet are rare today. This accords with our experience. The origin of such cysts is not known. There was no history of any operation, breast abscess, or aspiration of the breast in our cases.
Squamous carcinoma of the breast appears to be as rare as epidermoid cyst in the breast. Foot and Moore (1938) gave the incidence as $0.5 \%$ of all breast carcinomas. It is likely that this figure is misleading as it was the first case seen by the senior author in 25 years. Certainly no case has been described in the Fascicles of the Armed Forces Institute of Pathology (McDivitt et al., 1968), by Fisher et al. (1975) in a study of 1000 cases of breast carcinoma, or by Haagensen (1971) in a 50-year study of breast carcinoma.

No author has described more than seven cases; Menville (1936) described seven cases of epidermoid cyst of the breast in which the lining epithelium had undergone malignant change. The largest number of squamous carcinomas of the breast reported is four by both Deaver and McFarland (1917) and Stout (1932).

A summary of the previously described cases is given in the Table. The cases reviewed by Pasternack and Wirth (1936) have not been included in the Table as there is little clinical information given in that paper. Of the cases given in the Table, those described by Pasternack and Wirth (1936) and by James and Treip (1955) cannot be classed as pure squamous carcinoma of the breast and are most likely to be squamous metaplasia in either a medullary carcinoma or adenocarcinoma. Squamous metaplasia is not uncommon in breast malignancies (Cornog et al., 1971).

Squamous carcinomas usually arise in women aged $32-65$, the average age being 54.5 years. The left breast was affected in 13 cases of squamous carcinoma and the right in seven cases. The tendency for left-sided involvement in carcinoma of the breast has been noted before (Wynder et al., 1960). Only four of the women had borne children but in many of the cases the parity was not known. Prognosis varied with the tumour and ranged from death within four months with secondary tumour to 16 years in one of Menville's cases. The longest survival in a case of true infiltrating squamous carcinoma is 10 years (case 2). Since it is not known how many lymph nodes were found in some of the cases, these follow-up figures have a limited value.

The possible role of epidermoid cyst in the origin of squamous carcinoma is illustrated in both one of the present cases and the case quoted by Willis (1958). A possible alternative mode of origin of these tumours is by metaplastic change in ductal epithelium, as seen in case 2 . Such change is seen occasionally in benign cystic hyperplasia and in fibroadenoma (Salm, 1957). Certainly squamous metaplasia occurs not infrequently in adenocinoma of the breast (Cornog et al., 1971). No other histological type of tumour was present in our cases. 
Table Previously reported cases of squamous carcinoma of breast

\begin{tabular}{|c|c|c|c|c|c|c|c|}
\hline Author & Age & Side & Parity & History & $\begin{array}{l}\text { Size of } \\
\text { tumour }\end{array}$ & Associated pathology & Follow-up \\
\hline $\begin{array}{l}\text { Deaver and } \\
\text { McFarland (1917) }\end{array}$ & \multicolumn{7}{|c|}{ (4 cases-no details given) } \\
\hline $\begin{array}{l}\text { Johnson and } \\
\text { Lawrence (1917) }\end{array}$ & 53 & $\mathrm{~L}$ & NG & 3 weeks & 'Walnut' & $\begin{array}{l}\text { Irregular gland-like spaces lined } \\
\text { with irregular epithelium }\end{array}$ & NG \\
\hline Stout (1932) & $\begin{array}{l}50 \\
(4 \text { cases }\end{array}$ & $\stackrel{\mathrm{L}}{- \text { no det }}$ & $\begin{array}{l}\text { NG } \\
\text { ils given) }\end{array}$ & 3 months & \multicolumn{2}{|c|}{3 inches diam- } & NG \\
\hline \multirow[t]{4}{*}{ Menville (1936) } & $\begin{array}{l}\frac{53}{60} \\
61\end{array}$ & $\begin{array}{l}\text { L } \\
\mathbf{L} \\
\mathbf{L} \\
\mathbf{L}\end{array}$ & $\begin{array}{l}\text { NG } \\
\text { NG } \\
\text { NG } \\
\text { NG }\end{array}$ & $\begin{array}{l}? 1 \frac{1}{2} \text { days } \\
1 \text { month } \\
5 \text { weeks } \\
10 \text { years }\end{array}$ & $\begin{array}{l}- \\
-\end{array}$ & $\begin{array}{l}\text { Malignant lining in epithelial cyst } \\
\text { Malignant lining in epithelial cyst } \\
\text { Malignant lining in epithelial cyst } \\
\text { Malignant squamous and } \\
\text { basal cell lining }\end{array}$ & $\begin{array}{l}\text { Well } 3 \text { yr later } \\
\text { Well } 6 \text { yr later } \\
\text { Well } 16 \text { yr later } \\
\text { Lost to follow-up }\end{array}$ \\
\hline & 32 & $\mathbf{L}$ & NG & 2 years & - & $\begin{array}{l}\text { Malignant squamous cell } \\
\text { lining to cyst }\end{array}$ & $\begin{array}{l}\text { Died } 3 \text { yr later } \\
\text { ? cause }\end{array}$ \\
\hline & 64 & $\mathbf{L}$ & NG & 3 months & - & $\begin{array}{l}\text { Malignant squamous cell } \\
\text { lining to cyst }\end{array}$ & $\begin{array}{l}\text { Died } 1 \text { yr later } \\
\text { with secondaries }\end{array}$ \\
\hline & 53 & $\mathbf{R}$ & NG & 15 months & - & $\begin{array}{l}\text { Malignant squamous cell } \\
\text { lining to cyst }\end{array}$ & $\begin{array}{l}\text { Lost to follow-up } \\
6 \text { yr later }\end{array}$ \\
\hline $\begin{array}{l}\text { Pasternack and } \\
\text { Wirth (1936) }\end{array}$ & 60 & $\mathbf{R}$ & Single & 1 day & $7.0 \mathrm{~cm}$ & Adenocarcinoma & Well 2 mth later \\
\hline $\begin{array}{l}\text { Foot and Moore } \\
\text { (1938) }\end{array}$ & 53 & $\mathbf{R}$ & Para O & 20 years & $\begin{array}{l}8 \times 5 \times \\
4 \mathrm{~cm}\end{array}$ & $\begin{array}{l}\text { ?Intraduct carcinoma left } \\
\text { breast }\end{array}$ & $\begin{array}{l}\text { Died } 4 \text { mth later with } \\
\text { secondaries }\end{array}$ \\
\hline $\begin{array}{l}\text { Harrington and } \\
\text { Miller (1939) }\end{array}$ & 54 & $\mathbf{R}$ & Single & 2 months & NG & NG & $\begin{array}{l}\text { Died with second- } \\
\text { aries }\end{array}$ \\
\hline $\begin{array}{l}\text { Austin and Fidler } \\
\text { (1953) }\end{array}$ & 41 & $\mathbf{L}$ & Para 1 & 19 years & $2 \cdot 0 \mathrm{~cm}$ & $\begin{array}{l}\text { Carcinoma developing in a } \\
\text { fibroadenoma. }\end{array}$ & Well 5 mth later \\
\hline $\begin{array}{l}\text { James and Treip } \\
\text { (1955) }\end{array}$ & 51 & $\mathbf{R}$ & Single & 6 weeks & $12 \cdot 0 \mathrm{~cm}$ & $\begin{array}{l}\text { Medullary carcinoma. } \\
\text { Benign cystic hyperplasia }\end{array}$ & $\begin{array}{l}\text { Died } 19 \text { wk later } \\
\text { with secondaries }\end{array}$ \\
\hline Willis (1958) & $\begin{array}{l}52 \\
52\end{array}$ & $\begin{array}{l}\text { L } \\
\text { NG }\end{array}$ & $\begin{array}{l}\text { Single } \\
\text { Para } 0\end{array}$ & $\begin{array}{l}5 \text { weeks } \\
2 \text { years }\end{array}$ & $\begin{array}{l}6.0 \mathrm{~cm} \\
8.0 \mathrm{~cm}\end{array}$ & $\begin{array}{l}\text { Medullary carcinoma } \\
\text { Normal }\end{array}$ & $\begin{array}{l}\text { Well } 6 \text { mth later } \\
\text { Died } 3 \text { yr later }\end{array}$ \\
\hline $\begin{array}{l}\text { Arffmann and } \\
\text { Højgaard (1965) }\end{array}$ & 62 & L & Para 0 & & $\begin{array}{l}3 \times 4 \times \\
5 \mathrm{~cm}\end{array}$ & $\begin{array}{l}\text { Group of terminal ducts with } \\
\text { atypical epithelium }\end{array}$ & NG \\
\hline Essex and Rigg (1965) & 46 & $\mathbf{L}$ & Para 4 & 3 weeks & $2.0 \mathrm{~cm}$ & $\begin{array}{l}\text { Hyperplasia of epithelium in } \\
\text { ducts }\end{array}$ & Well $1 \frac{1}{2}$ yr later \\
\hline Jones (1969) & 65 & $\mathbf{R}$ & Para 2 & 1 month & $3 \times 2 \mathrm{~cm}$ & $\begin{array}{l}\text { Fat necrosis. Epithelial } \\
\text { hyperplasia }\end{array}$ & NG \\
\hline Cornog et al. (1971) & $(2 \mathrm{ct}$ & of $p$ & & & lividual clinical & 1 details given) & \\
\hline This study Case 1 & & $\mathbf{L}$ & Para 2 & 9 months & $\begin{array}{r}3.5 \times 3.5 \\
\times 3.0 \mathrm{~cm}\end{array}$ & $\begin{array}{l}\text { Sclerosing adenosis. } \\
\text { Benign cystic hyperplasia }\end{array}$ & Well 6 mth post op. \\
\hline Case 2 & 63 & $\mathbf{R}$ & Para 0 & 1 week & $5.0 \mathrm{~cm}$ diam & Cystic hyperplasia & Well 10 yr post op. \\
\hline
\end{tabular}

$\mathbf{N G}=$ not given

Cyst formation is a common feature in these tumours, as it is in squamous carcinoma elsewhere. The possibility remains that the central cyst in case 1 may have arisen because of necrosis. We think this unlikely because there was little necrosis elsewhere in the tumour or even in relation to the cyst and the cyst was lined by dysplastic epithelium. There have been no previous reports of infiltrating squamous carcinoma arising in a cyst. It appears that all of Menville's cases had malignant change in the lining epithelium but there was no invasion.

A prominent feature of case 1 was the pseudosarcomatous stroma. Such a reaction is not uncommon in squamous carcinoma in other parts of the body. Some of these stromal cells are spindleshaped epithelial cells admixed with fibrous tissue. Thus polypoid tumours of the larynx and pharynx have been described with a pseudosarcomatous stroma (Cornes and Lewis, 1966). Saphir and Vass (1938), in reviewing carcinosarcomas, would accept three or four tumours as pure carcinosarcomas out of a total of 153 cases reviewed.
These authors concluded that most carcinosarcomas are either collision or combination tumours but most commonly are primary carcinomas. Willis (1958) considered the possiblity of a myoepithelial origin for the tumour but rejected this for two reasons: firstly, because there was a clear derivation of the spindle cell growth from prickle cells, and secondly, because there was no evidence of any myoepithelial proliferation or of continuity of myoepithelium with the spindle cell growth.

We did not feel that myoepithelial cells played a part in the histogenesis of the present tumour. Unfortunately we were unable to carry out electron microscopy on this tumour to ascertain the ultrastructural characteristics of the stromal component.

\section{References}

Arffmann, E., and Højgaard, K. (1965). Squamous carcinoma of the breast: report of a case. Journal of Pathology, 90, 319-320.

Austin, W. E., and Fidler, H. K. (1953). Carcinoma developing in fibroadenoma of the breast. American 
Journal of Clinical Pathology, 23, 688-690.

Cornes, J. S., and Lewis, M. S. (1966). Polypoid carcinoma of the pharynx with sarcomatous or pseudosarcomatous stroma. British Journal of Surgery, 53, 340-344.

Cornog, J. L., Mobini, J., Steiger, E., and Enterline, H. T. (1971). Squamous carcinoma of the breast. American Journal of Clinical Pathology, 55, 410-417.

Deaver, J. B., and McFarland, J. (1917). The Breast; Its Anomalies, its Diseases and their Treatment, $\mathrm{p}$. 487. Heinemann, London.

Essex, W. B., and Rigg, B. M. (1965). Squamous carcinoma of the breast: report of a case. Australian and New Zealand Journal of Surgery, 34, 207-210.

Fisher, E. R., Gregorio, R. M., Fisher, B., et al. (1975) The pathology of invasive breast cancer: a syllabus derived from findings of the National Surgical Adjuvant Breast Project. Cancer, 36, 1-85.

Foot, N. C., and Moore, S. W. (1938). A fatal case of deep seated epidermoid carcinoma of the breast with widespread metastases. Americal Journal of Cancer, 34, 226-233.

Haagensen, C. D. (1971). Diseases of the Breast. 2nd edition, p. 600. W. B. Saunders, Philadephia.

Harrington, S. W., and Miller, J. M. (1939). Intramammary squamous cell carcinoma. Proceedings of the Mayo Clinic, 14, 484-487.

James, T. G. I., and Treip, C. (1955). Squamous-celled carcinoma of the breast. British Journal of Surgery, $42,650-654$
Johnson, R., and Lawrence, T. W. P. (1917). Two cases of squamous epithelial tumour of the breast. British Journal of Surgery, 5, 417-421.

Jones, E. L. (1969). Primary squamous-cell carcinoma of breast with pseudosarcomatous stroma. Journal of Pathology, 97, 383-385.

McDivitt, R. W., Stewart, F. W., and Berg, J. W. (1968). Tumours of the Breast (Atlas of Tumour Pathology, 2nd series, fasc. 2), p. 95. Armed Forces Institute of Pathology. Washington D.C.

Menville, J. G. (1936). Simple dermoid cysts of the breast. Annals of Surgery, 103, 49-56.

Pasternack, J. G., and Wirth, J. E. (1936). Adenoacanthoma sarcomatodes of the mammary gland: report of a case, with a critical review of the literature on squamous epithelium in intramammary tumours. American Journal of Pathology, 12, 423-435.

Salm, R. (1957). Epidermoid metaplasia in mammary fibro-adenoma with formation of keratin cysts. Journal of Pathology, 74, 221-222.

Saphir, O., and Vass, A. (1938). Carcinosarcoma. American Journal of Cancer, 33, 331-361.

Stout, A. P. (1932). Human Cancer, p. 296. Henry Kimpton, London.

Willis, R. A. (1958). Squamous cell mammary carcinoma of predominantly fibrosarcoma-like structure. Journal of Pathology, 76, 511-515.

Wynder, E. L., Bross, I. J., and Hirayama, T. (1960). A study of the epidemiology of cancer of the breast. Cancer, 13, 559-601. 